\title{
A desconstrução da educação iluminista em Heinrich von Kleist
}

\author{
[The deconstruction of Enlightened education in Heinrich von Kleist] \\ http://dx.doi.ors/10.11606/1982-88372339158
}

\section{Carina Zanelato Silva ${ }^{1}$}

\begin{abstract}
The Enlightenment pedagogy aimed to discuss the means of educating the human being both for good and intellectual independence, based on the principles of moral laws and of the supreme good. Thus, philosophy at that time has set the total responsibility of man for his acts as a parameter of its pedagogy, which entailed the indispensability of an education that has undergone a positive transformation in human nature, based on the maxim of moral judgement. Initially adept at such proposal, Heinrich von Kleist, right after his famous "Kantian crisis", began to contest the Enlightenment education model from a skeptical bias, since, for the author, the Kantian criticism showed the failures of this pedagogy according to a new view of reality. From this new perspective, the notions of freedom and morality assumed a new characterization, since it became impossible for Kleist to determine the results of these educational projects on human conduct. In face of this scenario, we will analyze in this paper two exemplary texts of how the author transposes such discussion into literature: in Allerneuster Erziehungsplan, Kleist inverts the logic of this education by proposing a "school of vice", whereas in Der Findling, the author contests the bourgeois moral values of family and supreme good, leading to a text full of violence and evil.
\end{abstract}

Keywords: Heinrich von Kleist; enlightenment pedagogy; Immanuel Kant.

Resumo: A pedagogia iluminista procurou debater os meios de se educar o ser humano para o bem e para a independência intelectual, fundando os pressupostos dessa formação nas leis morais do bem supremo. Para tanto, a filosofia da época usou como parâmetro de sua pedagogia a total responsabilidade do ser humano por seus atos, o que acarretou na imprescindibilidade de uma formação que operasse na natureza humana uma transformação positiva, pautada na máxima do bem moral. Inicialmente adepto a esta proposta, Heinrich von Kleist, logo após sua famosa "crise kantiana", passou a contestar o modelo de educação iluminista a partir de um viés cético, pois, para o autor, a nova visão de realidade aberta pelo criticismo kantiano evidenciou os fracassos dessa pedagogia. Sob este novo ponto de vista, as noções de liberdade e de moralidade ganharam uma nova caracterização, já que se tornou impossível para Kleist determinar quais seriam os resultados desses projetos educacionais na conduta humana. Diante deste cenário, analisaremos, neste artigo, dois textos exemplares de como esta discussão foi transposta pelo autor para a literatura: em Allerneuster Erziehungsplan, Kleist inverte a lógica desta educação ao propor uma "escola de vícios", enquanto que, em Der Findling (1811), o autor contesta os valores morais

\footnotetext{
${ }^{1}$ Universidade Estadual Paulista Júlio de Mesquita, Rodovia Araraquara-Jaú km 1, Araraquara, SP, 01049010, Brasil. E-mail: carinazs@ hotmail.com. ORCID: 0000-0001-7113-3087
} 
SILVA, C. Z. - A desconstrução da educação iluminista

burgueses da família e do bem supremo, desembocando em um texto repleto de violência e de maldade.

Palavras-chave: Heinrich von Kleist; pedagogia iluminista; Immanuel Kant.

\section{Introdução}

De acordo com Kant (2008: 1), em seu texto Beantwortung der Frage: Was ist Aufklärung? (Resposta à pergunta: O que é Iluminismo?, 1784), o Iluminismo caracteriza-se pela "saída do homem da sua menoridade de que ele próprio é culpado" (grifos do autor). A culpa imputada ao ser humano se refere à incapacidade deste de adquirir conhecimento sem o auxílio do outro, o que torna o próprio ser humano responsável por sua falta de determinação e coragem na busca do conhecimento ("Sapere aude!"). Com a avidez de um manifesto, este texto de Kant incita o leitor ao conhecimento e estabelece as diretrizes do projeto iluminista, que elege como bandeira a liberdade da razão em seu uso "público"2, ou seja, sem a dependência do nosso entendimento ao pensamento dos outros. O ser humano deve pensar por si, não se subjugando a outrem sem antes se esclarecer. Ainda que submetido às leis, o ser humano deve, assim, ser capaz de contestá-las, de expor suas falhas e refletir sobre elas (KANT 2008). Nesta mesma linha, Leibniz (1984: 420) nos diz que "é necessário que os cegos sejam guiados por aqueles que enxergam, ou que caiam na fossa, e não existe maior escravidão do que a do entendimento". O Iluminismo, dessa forma, seria a abertura de portas para a ação livre do entendimento, para o esclarecimento geral que possibilitaria ao ser humano pensar por si mesmo e sair dessa menoridade intelectual.

Este esclarecimento, contudo, deveria ser guiado pela lei moral para que, de fato, o ser humano atingisse sua maioridade intelectual. Segundo Moreau (1978), nos diálogos socráticos de Platão, questiona-se a possibilidade de se ensinar a virtude. Para Platão (MOREAU 1978: 27-28), a virtude, para que seja objeto pedagógico, deve ser vista como ciência, uma vez que seus princípios fundam-se "no conhecimento de um ideal e das razões supremas da ação"; inviabilizá-la como ciência tornaria a educação moral ineficaz. Assim, dentro da educação geral (Paideia), o saber da virtude (o conhecimento do bem) é aquele que dá sustentação a todos os outros saberes, pois prepara o ser humano para a ação ética, para o emprego ético destes saberes. Este conhecimento, portanto, é o único

\footnotetext{
${ }^{2}$ Vale lembrar que, para Kant, esse uso "público" da razão se refere à autoria no meio impresso, ou seja, aos letrados que expõem as suas teses e reflexões em público.
} 
SILVA, C. Z. - A desconstrução da educação iluminista

que interfere diretamente na conduta do ser humano, já que o conhecimento dos objetos do mundo é indiferente à vontade; apenas o conhecimento do bem (e do mal, consequentemente) leva o ser humano à ação, pois trabalha com o seu querer e com as suas aspirações, que se colocará em atividade para satisfazer estas instâncias. Por isso, para Platão (MOREAU 1978: 28), o desejo do ser humano nunca se voltará para aquilo que o fira como um mal; ele sempre escolherá um objeto que interfira no seu querer como um bem. Essa determinação da vontade pelo conhecimento do bem possibilitaria, assim, a educação moral do ser humano, pois o querer encontraria nessa educação um objeto que objetivamente representaria os valores da ciência da virtude que, apesar de serem expressos a partir de fórmulas externas, causariam sua verdadeira transformação internamente. Essa ciência poderia ser chamada de ciência dos fins, já que teria o aspecto interior da objetividade e atenderia à universalidade pretendida pela comunhão das vontades humanas. Assim, a educação por ele almejada seria aquela que não se baseia em um ensino utilitário (como a filosofia sofista), mas que visa uma finalidade em si mesma, o amor pelo próprio conhecimento.

A formação do ser humano, diante disso, não deve ser entregue ao subjetivismo na apreciação dos valores. Segundo Platão (MOREAU 1978: 32-33), assim como a matemática, a dialética, que visa o ajuizamento dos valores como instrumento de conhecimento do bem, deve proceder de forma objetiva para que seja estabelecida a ciência da virtude. Se não há dúvidas quanto às provas matemáticas, não deveria haver dúvidas também quanto aos valores expressos através da dialética, pois esta não trata das opiniões comuns acerca do bem e do mal, do justo e do injusto, do belo e do feio, mas sim da objetividade científica que só é possível de ser encontrada na "consciência em sua radical interioridade" (MOREAU 1978: 33). Baseada nesta certeza, a educação moral deveria ensinar apenas aquilo que é bom, justo e belo, preparando a vontade do ser humano para querer apenas o que represente estas máximas. Dessa forma, as imagens do vício e das paixões extremadas, que deturpam a moral, deveriam desaparecer das representações artísticas para que não possam ter qualquer influência que fuja à tríade do conhecimento do bem.

Assim sendo, podemos entender que o bem supremo e a virtude como ciência foram os alicerces para a formação pedagógica desde Platão. Tomando grande fôlego entre os séculos XVII e XIX, a pedagogia formadora para o bem teve como grandes representantes John Locke, Jean-Jacques Rousseau, Immanuel Kant, Johann Bernhard 
SILVA, C. Z. - A desconstrução da educação iluminista

Basedow, Joachim Heinrich Campe, Eduard Zeller, Johann Heinrich Pestalozzi, Johann Gottlieb Fichte, Wilhelm von Humboldt, Jean Paul e outros que dedicaram parte de (ou toda) sua filosofia para debater os meios de se educar o ser humano para o bem e para a independência intelectual, fundando os pressupostos dessa formação na lógica moral iluminista, voltada para o exemplo da virtude e da boa conduta, com o propósito de unir harmoniosamente todos os seres humanos sob o princípio comum das leis morais. Se a filosofia do século das luzes pregava que o ser humano é responsável por seus atos, é fundamental formá-lo para que, assim, seja operada na natureza humana uma transformação positiva que resulte em ações futuras pautadas no bem.

Heinrich von Kleist (1777-1811), filho desta era de pedagogos, primeiramente reafirmou a construção de seu Lebensplan (plano de vida) no sustentáculo da moralidade iluminista; porém, visto que a finalidade do ser humano e de seu conhecimento no mundo se tornou, a partir de sua leitura da filosofia de Kant, imprevisível, transferiu essa impossibilidade de se conhecer os efeitos das ações do ser humano para a sua formação. Se pensarmos o percurso de vida e de formação de Kleist por meio de fases, encontraremos a primeira, que se baseou em um modelo ideal de educação do Iluminismo, em que natureza, moralidade e conhecimento racional-científico representavam um contínuo, no qual o ser humano deveria se formar para que alcançasse a maioridade intelectual e pudesse viver uma liberdade genuína que guiasse seus passos tanto intelectual quanto moralmente. Como Rousseau, Kleist acreditava que a natureza preservava em seu seio a finalidade moral que o ser humano deveria alcançar para encontrar a felicidade plena; nela, portanto, ele deveria se espelhar para que atingisse a finalidade de sua espécie. Já de acordo Fichte e Kant, o autor via o ato pedagógico como meio de libertação, em que o conhecimento se torna a principal ferramenta para que o ser humano se desvencilhe da tutela intelectual.

Contudo, após a crise kantiana, encontramos uma segunda fase desse veio pedagógico de Kleist que consiste na transformação desse modelo de educação iluminista a partir de um viés cético, o qual reflete sobre o papel da capacidade humana de aprender e sobre quais processos de formação garantiriam ao ser humano uma educação mais completa para essa nova visão de realidade adquirida pelo criticismo kantiano. As noções de liberdade e de moralidade ganham uma nova caracterização, já que se torna impossível para Kleist (1982) determinar ou prever quais serão os resultados dos projetos educacionais até então vigentes na conduta humana, pois o ser humano é, em si mesmo, 
SILVA, C. Z. - A desconstrução da educação iluminista

contraditório, e está ligado, pelo destino ou pelo fim dado a ele pela natureza, a milhares de outras instâncias que muitas vezes se sobrepõem à educação formal dada pelos pais ou pela escola. Não há como considerar uma lei universal que una a humanidade sob o princípio do bem, visto que a moralidade se torna subjetiva, ou seja, cada indivíduo desenvolverá sua moral de acordo com as milhares de situações que o afetam na experiência, tanto interna quanto externa. A transgressão e o vício são, dessa forma, possíveis efeitos até mesmo de uma educação que tenha se voltado exclusivamente para o desenvolvimento do princípio do bem supremo.

Diante dessa nova visão, exploraremos, neste artigo, o processo de desconstrução da pedagogia iluminista empreendido por Kleist a partir de dois textos literários: Allerneuester Erziehungsplan e Der Findling.

\section{Escola de vícios: o Allerneuester Erziehungsplan de Kleist}

Heinrich von Kleist passa a contestar a educação iluminista a partir da capacidade do ser humano de aprender algo desse modelo de formação e o primeiro texto literário em que esta discussão aparece intitula-se Allerneuester Erziehungsplan (O mais novo plano de educação), publicado em seu jornal Berliner Abendblätter, entre outubro e novembro de 1810. Ao compor este texto, Kleist ficcionaliza todos os elementos necessários para o estabelecimento da comunicação a partir desse jornal, que é um suporte real que veiculará a mensagem. Com ares de "carta ao editor", o texto estabelece um diálogo muito interessante entre enunciador e enunciatário: o autor da carta é C. J. Levanus, um vicediretor de escola que analisa os modelos pedagógicos iluministas até então vigentes, propondo um novo plano educativo que revolucionaria a formação dos jovens. Contudo, essa carta é introduzida por um comentário do editor do jornal - também fictício -, que pontuará que o texto que segue deve ser visto como uma prova dos frequentes novos projetos educacionais, os quais intentam ora seduzir as pessoas para uma ideia ora produzir algo novo pelo puro vício da novidade. Assim, de forma irônica, o editor critica o turbilhão de teorias pedagógicas que estavam surgindo na época, incluindo o texto de Levanus nesta miríade, fazendo um alerta ao leitor para que este não considere seriamente o que será exposto, pois a inventividade apresentada não passa de mais uma tentativa de se sobrepor ao que já existe. Estabelecido o diálogo inicial, a carta será permeada por comentários sarcásticos do editor, o que dará ao texto um tom humorístico e irônico, mas que (NoBILE 1999: 51), ao invés de cumprirem com o seu propósito de ferir a proposta 
SILVA, C. Z. - A desconstrução da educação iluminista

do autor Levanus, reafirmam a contestação dos projetos pedagógicos vigentes, pois apresentam argumentos porosos, sem consistência.

Levanus começa a sua carta - dirigida ao "Hochgeehrtes Publikum"3 comparando a disposição moral do ser humano à lei física da atração e repulsão elétricas. Para ele (KLEIST 1982: 330), as pessoas em meio moral são iguais aos elétrons ${ }^{4}$ : quando encontram-se em estado neutro e se reúnem com iguais, se repelem; contudo, quando se encontram em estado positivo ou negativo, assumem uma condição contrária a estes: "sein Wesen sogar wird, um mich so auszudrücken, gänzlich in den entgegengesetzten Pol hinübergespielt; er nimmt die Bedingung + an, wenn jener von der Bedingung - und die Bedingung -, wenn jener von der Bedingung + ist"5. A lei da contradição (Gesetz des Widerspruchs) do comportamento do corpo eletricamente neutro em um campo elétrico explicaria, dessa forma, não só o nosso desejo incontrolável de contradizer o outro mesmo que nós estejamos errados -, mas também o ciclo observado na formação das crianças, uma vez que, para Kleist, as filhas de pais brilhantes geralmente se formam de maneira insignificante, e vice-versa:

Wer dies Gesetz recht begreift, dem wird die Erscheinung gar nicht mehr fremd sein, die den Philosophen so viel zu schaffen gibt: die Erscheinung, daß große Männer, in der Regel, immer von unbedeutenden und obskuren Eltern abstammen, und ebenso wieder Kinder groß ziehen, die in jeder Rücksicht untergeordnet und geringartig sind. Und in der Tat, man kann das Experiment, wie die moralische Atmosphäre, in dieser Hinsicht, wirkt, alle Tage anstellen. Man bringe nur einmal alles, was, in einer Stadt, an Philosophen, Schöngeistern, Dichtern und Künstlern, vorhanden ist, in einen Saal zusammen: so werden einige, aus ihrer Mitte, auf der Stelle dumm werden; wobei wir uns, mit völliger Sicherheit, auf die Erfahrung eines jeden berufen, der einem solchen Tee oder Punsch einmal beigewohnt hat. (KLEIST 1982: 332) ${ }^{6}$

A contradição para Kleist reside no próprio processo formativo. Seguindo a lei da contradição, o ambiente de formação da criança a disporia de acordo com o campo magnético, que a atrairia para o brilhantismo, se o polo fosse insignificante, ou para a

\footnotetext{
3 "Honrado público."

${ }^{4}$ É interessante notar que Kleist sempre deixou explícita em suas cartas uma crença na similaridade entre as leis e ações do meio físico e do meio moral. Para ele, quase tudo que acontece no mundo físico tem seu equivalente no mundo moral, o que torna a observação da natureza útil não apenas para que o ser humano aprenda a viver nesse mundo físico, mas que também compreenda, a partir dele, o mundo moral.

5 "Sua própria natureza se torna, para me expressar mais claramente, completamente impelida ao polo oposto; assume a condição + se a condição é - e a condição - se a condição é +."

6 “Aquele que compreende esta lei não será mais alienado pelo fenômeno [Erscheinung], que dá muito o que fazer aos filósofos: a aparência de que os grandes homens, sempre descendentes de pais insignificantes e obscuros, como regra, também criam seus filhos desta maneira, subordinados e insignificantes em todos os aspectos. E de fato, nesse sentido, pode-se fazer o experimento surtir efeito todos os dias, como o ambiente moral. Basta reunir uma única vez em um salão os personagens que existem em uma cidade, como filósofos, estetas, poetas e artistas: assim, alguns ficam imediatamente estúpidos; por isso, com toda certeza, chamamos pela experiência de quem já provou algum vez de tal chá ou ponche.”
} 
SILVA, C. Z. - A desconstrução da educação iluminista

insignificância, se o polo fosse o brilhantismo. Transferindo esta ideia para o projeto educacional baseado na imitação, o ditado de que um mau comportamento corrompe um bom torna-se, dessa forma, restrito, o que o faz criticar diretamente as propostas de Basedow e Campe em relação ao desestímulo ao vício. Para Levanus (KLEIST 1982: 333), os fracassos dessa educação iluminista se dão porque 1) as escolas por ela proposta se baseiam na imitação de bons exemplos, ao invés de elaborarem bons princípios no coração destes jovens e, além disso, 2) estas instituições não produziram nada de significativo para a humanidade, 3) a não ser os ocasionais exemplos ruins, estes sim dentro do princípio de contradição, produtivos para a verdadeira formação dos jovens. Para o vice-diretor,

Und wahrlich, wenn man die gute Gesellschaft, mit der schlechten, in Hinsicht auf das Vermögen, die Sitte zu entwickeln, vergleicht, so weiß man nicht, für welche man sich entscheiden soll, da, in der guten, die Sitte nur nachgeahmt werden kann, in der schlechten hingegen, durch eine eigentümliche Kraft des Herzens erfunden werden muß. (KLEIST 1982: 332$)^{7}$

Este "eigentümliche Kraft des Herzens" não se bastaria na passividade da imitação, mas colocaria o ser humano em movimento, podendo ativar nele aquele princípio do bem supremo de que fala Kant ao condenar qualquer projeto educacional baseado na imitação de princípios morais. Somente a imitação do bom exemplo não desperta este poder de ação, o que faz com que Levanus acredite que seria mais proveitoso fundar uma escola de vícios (Lasterschule) ou uma escola antagônica (gegensätzische Schule), que ensinaria, na lógica da lei da atração e da repulsão, a virtude (Tugend) através do vício (Laster):

Demnach werden für alle, einander entgegenstehende Laster, Lehrer angestellt werden, die in bestimmten Stunden des Tages, nach der Reihe, auf planmäßige Art, darin Unterricht erteilen: in der Religionsspötterei sowohl als in der Bigotterie, im Trotz sowohl als in der Wegwerfung und Kriecherei, und im Geiz und in der Furchtsamkeit sowohl, als in der Tollkühnheit und in der Verschwendung. ${ }^{8}$ (KLEIST 1982: 334)

A ironia desta passagem se torna clara: o processo de mimesis a partir do exemplo para o bem coloca em evidência os inúmeros casos de crianças e jovens que foram educados para este bem supremo e que acabaram por cair na transgressão e no vício. Não

\footnotetext{
7 "E, verdadeiramente, quando se compara a boa sociedade com a má, em relação à faculdade de desenvolver o costume, não se sabe o que escolher, pois, no bem, o costume só pode ser imitado, enquanto que no mal, ao contrário, deve ser inventado por um poder peculiar do coração."

8 "Assim, para todos os vícios adversos, serão empregados professores que, em determinadas horas do dia, depois da ordenação [dos alunos], de forma sistemática, as ensine: tanto na zombaria religiosa quanto no fanatismo; tanto na teimosia quanto no menosprezo e na bajulação; e tanto na ganância quanto na covardia, na imprudência e no desperdício."
} 
SILVA, C. Z. - A desconstrução da educação iluminista

temos pleno controle do que a criança e o jovem tomam como exemplo de conduta, e isso faz com que não possamos prever os resultados desta educação formal, dada não só na escola, mas também no meio familiar. É interessante observar que Kleist critica duramente o Classicismo por seu processo de educação estética, que se baseia em modelos de imitação que impossibilitam o acesso do ser humano à beleza e à verdade. Em Brief eines jungen Dichters an einen jungen Maler (Carta de um jovem poeta a um jovem pintor), Kleist nos diz que não compreende a posição de um artista que gasta anos para copiar a obra de seu grande mestre, uma vez que "Kunst etwas so Unendliches ist"9 (KLEIST 1982: 336), e não deve se submeter à imposição da cópia, pois a imaginação será sempre atuante e desafiadora da imitação. A prática imitativa mata, segundo ele (KLEIST 1982: 336-337), a imaginação, pois, ainda que ela ensine as técnicas empregadas pelo artista, o processo inventivo, essencial, nunca poderá ser ensinado. Sua recomendação é, dessa forma, a de que o artista possa definir o seu modelo a partir dos mestres, mas que deva também, antes de tudo, colocar o seu gênio na obra de arte, para que ela o diferencie de qualquer outro, processo muito similar ao gênio por ele atestado na formação pedagógica do ser humano.

Em um de seus epigramas, Kleist já havia advertido para esta falha dos projetos educacionais:

Die unverhoffte Wirkung.

Wenn du die Kinder ermahnst, so meinst du, dein Amt sei erfüllet.

Weißt du, was sie dadurch lernen? - Ermahnen, mein Freund. (KLEIST 1982: 24) ${ }^{10}$

Assim, a moralidade vista apenas nestas bases do bom exemplo (imitação) e da repreensão é para Levanus “mißlich” (inconveniente/desagradável), pois

das Kind ist kein Wachs, das sich, in eines Menschen Händen, zu einer beliebigen Gestalt kneten läßt: es lebt, es ist frei; es trägt ein unabhängiges und eigentümliches Vermögen der Entwickelung, und das Muster aller innerlichen Gestaltung, in sich. (KLEIST 1982: $335)^{11}$

Deste modo, Levanus critica todas as teorias pedagógicas que veem a criança como uma massa que pode ser formada a partir daquilo que almeja o seu preceptor, dialogando mais diretamente com Rousseau e seu Emílio. Para o filósofo suíço, as

\footnotetext{
9 "A arte é algo de infinito."

10 "O efeito infeliz. Quando você adverte as crianças, você acha que seu trabalho está cumprido. Você sabe o que eles aprendem com isso? - A advertir, meu amigo."

11 "A criança não é uma cera, que, em mão humana, pode ser modelada de qualquer forma: ela vive, é livre; ela traz em si uma faculdade de desenvolvimento independente e característica, e o modelo de toda uma formação interna."
} 
SILVA, C. Z. - A desconstrução da educação iluminista

crianças que ainda não tiveram seus sentimentos desenvolvidos podem ser induzidas na imitação de atos habituais, pois “o homem é imitador, até o animal o é; o gosto da imitação é da natureza bem ordenada; mas degenera em vício na sociedade" (RouSSEAU 1995: 94). Assim, essa possibilidade de imitação, segundo Rousseau (1995), é garantida apenas enquanto a criança não se desenvolveu racionalmente. A partir do momento em que passa a ter consciência de seus sentimentos e da sua razão, ela deve seguir estes princípios única e exclusivamente por sua vontade. Esta educação não garante, portanto, que o seu resultado final seja positivo, na medida em que o ser humano formado tem completa autonomia sobre aquilo que fará de sua vida, o que faz com que a ordem natural ensinada por Rousseau a Emílio possa degenerar em vício, pois, socialmente, essa ordem estabelecida possui a interferência de inúmeros outros motivos que conduzem o amor próprio do ser humano. À vista disso, na filosofia de Rousseau, a formação desse homem social se estabelece na reconstrução de uma natureza que não está ligada ao meio selvagem - como muitos interpretaram o sentido da expressão "bom selvagem" - mas sim à finalidade, à vocação do ser humano diante de sua verdadeira natureza, que é a obediência às leis morais da razão em consonância com os mandamentos religiosos de Deus. Nesta linha, também Kant estabelece o princípio do amor próprio como uma heteronomia na ação da vontade humana, já que não se segue o princípio do sumo bem, e deixa-se interferir os inúmeros móbiles externos que se interligam na disposição moral do ser humano. Levanus acredita, juntamente com estes filósofos, que há muitas forças que influenciam a conduta do ser humano, reafirmando em sua proposta que a educação não é a única responsável pela formação do ser humano, por isso não se deve dar uma importância excessiva a ela:

Eltern, die uns ihre Kinder nicht anvertrauen wollten, aus Furcht, sie in solcher Anstalt, auf unvermeidliche Weise, verderben zu sehen, würden dadurch an den Tag legen, daß sie ganz übertriebene Begriffe von der Macht der Erziehung haben. Die Welt, die ganze Masse von Objekten, die auf die Sinne wirken, hält und regiert, an tausend und wieder tausend Fäden, das junge, die Erde begrüßende, Kind. Von diesen Fäden, ihm um die Seele gelegt, ist allerdings die Erziehung einer, und sogar der wichtigste und stärkste; verglichen aber mit der ganzen Totalität, mit der ganzen Zusammenfassung der übrigen, verhält er sich wie ein Zwirnsfaden zu einem Ankertau; eher drüber als drunter. (KLEIST 1982: 334) $)^{12}$

\footnotetext{
12 "Pais, que não queiram confiar suas crianças a nós, com medo de as verem corrompidas pelo instituto de uma maneira inevitável, deveriam, assim, rever suas noções completamente exageradas sobre o poder da educação. O mundo, toda a massa de objetos que afetam os sentidos, detém e regula milhares e milhares de fios, que a jovem criança recebe da terra. Entre estes fios, colocados sobre sua alma, a educação é, de fato, um, talvez até o mais importante e mais forte; mas comparada à totalidade das interrelações dos outros fios, a educação é como um pedaço de linha diante de um cabo de âncora."
} 
SILVA, C. Z. - A desconstrução da educação iluminista

Porém, diferentemente desses filósofos, percebe-se que Levanus acredita numa regulação e numa determinação destes fios pelo mundo, ou seja, há o quesito destino, que poda a noção de liberdade da criança antes afirmada. O determinismo é muito marcante nos textos de Kleist, cujas ações do ser humano já estão previamente condicionadas, restando-lhe apenas procurar viver a vida de forma justa e honesta, mas sem garantias de que isso de fato ocorrerá. Para Kant,

Vivemos em uma época de disciplina, de cultura e de civilização, mas ela ainda não é a da verdadeira moralidade. Nas condições atuais pode dizer-se que a felicidade dos Estados cresce na mesma medida que a infelicidade dos homens. E não se trata ainda de saber se seríamos mais felizes no estado de barbárie, no qual não existiria toda essa nossa cultura, do que no atual estado. De fato, como poderíamos tornar os homens felizes, se não os tornamos morais e sábios? Desse modo, a maldade não será diminuída. (KANT 2002: 28)

Kant apresenta, aqui, um estado de consciência do ser humano que se assemelha muito ao descrito por Kleist em seu Über das Marionettetheater: no passado, vivíamos em um estado de barbárie e de inocência em que estava pressuposta (mas, em Kant, não garantida) uma felicidade plena. Contudo, no presente, vivenciamos um estado de cultura e de meia consciência de nossa destinação, que ainda não alcançou a verdade que a moralidade plena nos proporcionaria. Há, assim, uma terceira condição, de sabedoria e moralidade absolutas, que tornaria os homens felizes e os livraria da maldade. Kant demonstra, assim, total consciência dessa separação e da impossibilidade da plena felicidade do ser humano enquanto este não alcançar o estado de sabedoria e de felicidade a partir da moralidade. O seu propósito educativo, dessa forma, visa uma nova educação, que atenda a esses quesitos e leve o ser humano a, finalmente, cumprir sua destinação moral, não como indivíduo, mas como espécie.

É interessante observar que, para Kant, a única ação do ser humano que pode ser considerada verdadeiramente livre é aquela que parte da observação rigorosa da lei moral. Dessa forma, segundo Vincenti, “o livre-arbítrio está longe de se confundir com a liberdade moral" (VINCENTI 1994: 21-22), pois nada nos garante que, na escolha dos móbiles de ação, tenhamos aplicado, de fato, a lei moral como fundamento da máxima e não uma causa externa que inseriria um princípio outro, não representativo da liberdade moral. Assim, ainda que possua poder de escolha, o livre-arbítrio não é verdadeiramente livre, pois se deixa condicionar pela natureza externa, impossibilitando que a liberdade moral atue nele de forma pura. Dessa maneira, a contingência desta proposição se assemelha muito ao determinismo kleistiano de um arbítrio que está condicionado aos 
SILVA, C. Z. - A desconstrução da educação iluminista

diversos fios que o ligam ao mundo empírico. Idealmente, Kant propõe uma total independência moral do ser humano que consegue basear-se apenas na lei do dever; porém, não há possibilidade de saber se a conduta do ser humano está pautada nesta pureza, o que faz com que, empiricamente, a contingência atue e se mostre de forma mais clara, impedindo, assim, esta caracterização da verdadeira liberdade moral. Kleist, consciente desta contingência, atribui uma aparência de poder de escolha ao livre-arbítrio que nos atrela às disposições culturais, sociais, econômicas e naturais do meio em que vivemos, fazendo com que o retorno clandestino ao paraíso, provido de uma total sabedoria, não possa ser atendido por esse modelo racional iluminista, pois foi exatamente esse modelo que o levou ao ceticismo.

Em seu Reden an die deutsche Nation (Discurso à nação alemã, 1807-1808), Fichte (1994) nos diz que a má utilização da liberdade (em termos de livre escolha do arbítrio) é que acarreta os males da humanidade e que, por isso, o ser humano deve ser educado para que não use dessa liberdade de forma a cometer atrocidades, uma vez que o arbítrio, solto das amarras das leis morais, pode ser perverso. A partir disso, Vincenti (1994) diz que, apesar de Fichte e Kant acreditarem em uma educação pautada na liberdade, que prepara o ser humano para um desvencilhamento da tutela intelectual, suas filosofias da educação baseiam-se em coerção e adestramento ${ }^{13}$, já que a criança é submetida, em Fichte, a uma legislação penal severa que a torna capaz de exercer moralmente o seu livre-arbítrio e, em Kant, a uma obediência cega que a ensina a usar o livre-arbítrio através da ideia de punição. Estas formas pedagógicas seriam necessárias para que o livre-arbítrio não se desviasse do caminho da boa vontade; a coerção e o adestramento, deste modo, deveriam ser vistos sob o aspecto de uma educação moral positiva (VINCENTI 1994: 27), pois operariam na aplicação da lei do dever, na máxima que norteia nossa conduta (com Kant) e na subordinação do individual ao coletivo como forma de desmantelar o egoísmo (com Fichte). Ainda assim, essa pedagogia não poderia despertar no seu aluno o medo ao castigo pura e simplesmente para que este cumpra o seu dever moral, mas sim deve atender ao propósito de que esta lei é obedecida por um princípio desinteressado, ou seja, pelo simples amor à lei em si mesma.

\footnotetext{
${ }^{13}$ É digno de nota que Kant acredita (assim como Rousseau) que a criança, em sua fase inicial, não possui ainda humanidade, o que viabiliza a imposição das leis do dever (através do adestramento) sem que isto fira a sua liberdade moral. Somente a partir do momento em que a moralidade se desenvolve é que a criança poderá, de fato, exercer a liberdade da sua vontade e não ter mais esta educação impositiva.
} 
SILVA, C. Z. - A desconstrução da educação iluminista

Não obstante, para alcançar este amor pela lei, Fichte (1994: 102) propõe uma pedagogia que aboliria a liberdade da vontade justamente para que esta fosse direcionada para a finalidade descrita no seu Bestimmung des Menschen, ou seja, a de educar o ser humano para que este atinja o seu propósito enquanto ser racional. A livre-vontade do aluno, segundo ele, só ocasionou até o presente momento uma ineficácia do sistema educacional, na medida em que essa liberdade permite ao aluno a oscilação entre o bem e o mal, o que evidencia a sua incapacidade de formar a vontade para o bem, finalidade última da espécie humana. Assim, para Fichte

Ao contrário, no terreno que empreendesse modelar, a nova educação deveria justamente consistir no aniquilamento total da liberdade da vontade; ao mesmo tempo em que engendraria na vontade a rigorosa necessidade das decisões e nela tornaria impossível a contradição. Poder-se-ia, então, contar firmemente com uma tal vontade e confiar nela. (FICHTE 1994: 102)

A nova educação estabilizaria, dessa forma, a vontade do homem, não permitindo a contraditoriedade da oscilação. Vale ressaltar que Fichte (VINCENTI 1994: 77) condena qualquer forma de adestramento, pois o ser humano deve ser capaz de atribuir a si mesmo suas próprias determinações, o que seria inviável se ele fosse produzido para atender às necessidades do outro, como em uma educação em que o preceptor prepara o seu aluno para ser aquilo que ele almeja como ideal, mas que ele mesmo não conseguiu alcançar. Em um de seus epigramas, Kleist pontua exatamente esta forma de educação:

\section{Der Pädagog.}

Einen andern stellt er für sich, den Aufbau der Zeiten

Weiter zu fördern; er selbst führet den Sand nicht herbei. (KLEIST 1982: 24) ${ }^{14}$

Contudo, Fichte (1994: 105) acredita que a nova educação deve estimular no espírito do aprendiz a imagem de um estado de coisas que provoque uma "satisfação estimulante", diferente, portanto, da realidade que o circunda, e que esboce um modelo, um exemplo que leve o espírito a desejar este estado de coisas que é, em si, o puro estado de ordem das leis da razão estabelecido socialmente. A legislação vigente dessa nova ordem social deveria ser "rigorosíssima", uma vez que a vida deste indivíduo se pautaria no coletivo, renunciando a qualquer ato de egoísmo que pudesse surgir em seu espírito (FICHTE 1994: 114).

\footnotetext{
14 “O pedagogo. Ele dispõe um outro para si, que o continua na estrutura do tempo; ele mesmo não causa nada."
} 
Assim como em Platão, Vincenti diz que, em Fichte e Kant,

a moralidade surge como indispensável se quisermos desenvolver todas as disposições a natureza humana, orientando-as para o bem. Ela é, então, a pedra angular de um plano de educação, no sentido de que não se poderia empreender racionalmente a construção de um tal edifício se não se estivesse seguro de poder finalmente instalá-la. (VINCENTI 1994: 63)

Não há como o ser humano alcançar a finalidade de sua espécie sem baseá-la em uma moralidade orientada para o bem. Todos os projetos pedagógicos, dessa forma, devem utilizá-la como elemento primordial, subordinando os demais conhecimentos a esta ciência essencial. Além disso, deve-se afirmar a autonomia do aluno enquanto sujeito, não o tornando dependente intelectualmente de seu tutor, mas capaz de adquirir conhecimentos por si mesmo ${ }^{15}$.

À vista disso, Levanus estabelece uma forte oposição a estes sistemas educacionais impositivos, baseados em uma moralidade e em um modelo ideal que não garante sucesso algum em sua aplicação precisamente porque esse ideal é incompatível com o mundo empírico no qual vivemos. Além disso, a educação recebida pelo ser humano sempre é proveniente de outro ser humano que também foi educado, o que torna o alcance desse ideal cada vez mais improvável, levando-nos a questionar até que ponto há a pureza desse dever nos ensinamentos que nos são transmitidos. Como encontrar a heteronomia na aplicação da máxima se não temos certeza de como é, de fato, a lei pura do dever? ${ }^{16}$ Dessa forma, no fim, a sua escola de vícios não poderia ser criticada, pois a sua missão, o seu produto final não diferiria em nada das outras instituições iluministas:

In unsrer Schule wird, wie in diesen, gegen je einen, der darin zu Grunde geht, sich ein andrer finden, in dem sich Tugend und Sittlichkeit auf gar robuste und tüchtige Art entwickelt; es wird alles in der Welt bleiben, wie es ist; und was die Erfahrung von

\footnotetext{
${ }^{15}$ Para Fichte (apud VINCENTI 1994: 76), “Cada animal é o que é; apenas o homem, originalmente, não é coisíssima nenhuma. O que deve ser, é preciso que ele se torne; e, sendo dado que de qualquer modo ele deve ser um ser para si, é preciso que se o torne por si mesmo. A natureza arrematou todas as obras, unicamente para o homem ele não interferiu, e foi precisamente desse modo que confiou-o a si mesmo. A capacidade de ser formado, como tal, é a característica inerente à humanidade”. Kant (2002: 12) também partilha da mesma opinião: "A disciplina transforma a animalidade em humanidade. Um animal é por seu próprio instinto tudo aquilo que pode ser; uma razão exterior a ele tomou por ele antecipadamente todos os cuidados necessários. Mas o homem tem necessidade de sua própria razão. Não tem instinto, e precisa formar por si mesmo o projeto de sua conduta. Entretanto, por ele não ter a capacidade imediata de o realizar, mas vir ao mundo em estado bruto, outros devem fazê-lo por ele".

${ }^{16}$ Kant (2002) acreditava que esse círculo vicioso poderia ser rompido se um ser humano conseguisse educar a si mesmo, sem a necessidade de se educar a partir do outro. Dando sequência a esta ideia, Fichte dirá que o círculo educador educado pode ser desfeito a partir de uma pedagogia que vise o apelo à consciência do ser enquanto determinante de sua humanidade. O ser humano deve ter conhecimento prévio do seu querer e da sua ação como formas de liberdade; este conhecimento é despertado por uma consciência que, por sua vez, é acionada por outro ser racional, o pedagogo. A relação que se dá aqui é entre seres racionais em um patamar de igualdade (educação recíproca, que exclui qualquer relação de influência e subordinação) (VINCENTI 1994).
} 
SILVA, C. Z. - A desconstrução da educação iluminista

Pestalozzi ${ }^{17}$ und Zeller und allen andern Virtuosen der neuesten Erziehungskunst, und ihren Anstalten sagt, das wird sie auch von uns und der unsrigen sagen: „Hilft es nichts, so schadet es nichts"“. ${ }^{18}$ (KLEIST 1982: 335)

A contradição de sua inovação reside no produto final: assim como no ensino das outras instituições, o efeito não é garantido, mas também não fará mal algum além daquele encontrado nas escolas tradicionais. Humoristicamente, Kleist desdenha, em outro epigrama, de um possível sucesso que as pedagogias de Pestalozzi e Fichte poderiam alcançar:

P... und F...

Setzet, ihr traft's mit eurer Kunst und erzögt uns die Jugend

Nun zu Männern wie ihr: lieben Freunde, was wär's? (KLEIST 1982: 24) $)^{19}$

Ainda que esta pedagogia alcance sucesso, isto não terá importância alguma, já que o ser humano ainda viverá em um estado de consciência intermediária que lhe impossibilita o verdadeiro conhecimento; o resultado de um processo mimético ou a coerção daí proveniente não teria nenhum mérito. Apenas uma educação natural (NOBILE 1999: 53) teria possibilidades de sucesso, pois aproximaria o aluno de sua verdadeira vocação, ao passo que as tentativas artificiais, como a transposição do amor familiar para a instituição escolar (em Pestalozzi) ou a simulação de um estado ideal (em Fichte), que intentam recriar este ambiente natural de educação, estão fadadas ao fracasso. Em uma carta de 16 e 18 de novembro de 1800, Kleist nos diz:

Mir leuchtet es immer mehr und mehr ein, daß die Bücher schlechte Sittenlehrer sind. Was wahr ist sagen sie uns wohl, auch wohl, was gut ist, aber es dringt in die Seele nicht ein. Einen Lehrer gibt es, der ist vortrefflich, wenn wir ihn verstehen; es ist die Natur. ${ }^{20}$ (KLEIST 1982: 592)

\footnotetext{
${ }^{17}$ Para Pestalozzi (MEYLAn 1978), a educação familiar seria o elemento fundamental de formação da criança, pois o seio familiar proveria toda a formação necessária para a vida a partir do amor, que interfere efetivamente na formação da criança, sendo a escola apenas uma complementação desta formação. A educação elementar é, dessa forma, a educação para a humanidade, que deveria ser conforme à natureza para que atendesse ao princípio da virtude.

18 "Na nossa escola, como nestes [institutos], encontrar-se-á aqueles que perecem assim como aqueles outros em que a virtude e a moral se desenvolvem de forma robusta e capaz; tudo permanecerá no mundo tal qual é; e o que a experiência de Pestalozzi e Zeller e todos os outros virtuosos da mais nova arte da educação e suas instituições dizem, ela dirá sobre nós e para nós: 'Se isso não ajudar, também não fará mal'."

19 "P... e F... Supondo que vocês atingiram o alvo de suas artes e os jovens foram educados para serem homens como vocês: queridos amigos, e daí?"

20 "Cada vez mais me parece que os livros moralistas são ruins. Eles nos dizem o que é verdadeiramente certo, também certo, o que é bom, mas não penetram na alma. Há um professor que é excelente, se o entendemos; é a natureza."
} 
SILVA, C. Z. - A desconstrução da educação iluminista

Faz-se necessário observar, ainda, que o nome do autor do texto escolhido por Kleist faz clara referência ao livro Levana oder Erziehlehre, de Jean Paul, publicado em 1807. Neste livro (NoBILE 1999: 20), o autor resgata a figura da deusa romana Levana, protetora das crianças recém-nascidas, como metáfora do tempo de educação dado exclusivamente pela mãe ao filho - cujo laço de parentesco era certo - até que este pudesse passar para a tutoria de seu pai - o qual ainda não tinha certeza de seu laço sanguíneo. Para Jean Paul, a influência da mãe na formação da criança durante este período era extremamente nociva e esta somente iria adquirir os verdadeiros conhecimentos para a vida e ter o reparo dos "danos" causados pela mãe a partir da educação do pai. Desta maneira, educar a mãe seria essencial para que ela ferisse o menos possível a formação do filho. Diante da lógica kleistiana aqui abordada, o nome Levanus se apresenta de maneira sarcástica e crítica ao processo educacional exposto por Jean Paul. Se é a mulher que perturba a formação inicial do homem e o pai é o "reparador dos danos", atribui-se a um homem a autoria de um texto que prega precisamente a inserção da criança no vício e na transgressão para que ela possa se desenvolver como pessoa digna. A pedagogia de Kleist se apresenta, assim, sob o signo da subversão e da sátira, pois, para ele, a forma como adquirimos conhecimento e como idealizamos o processo pedagógico formal é um despropósito. Dessa forma, a literatura constrói-se, neste texto, a partir de um jogo entre real e fictício que enfatiza o papel inovador e crítico da mensagem a ser transmitida.

\section{$3 \bigcirc$ fracasso da educação iluminista sob o signo da maldade em Der Findling}

$\mathrm{Na}$ literatura de Kleist, também podemos encontrar como forma de representação desta falha no sistema educacional iluminista descrita acima o conto Der Findling (O adotado, 1811) que, criticamente, coloca em xeque uma educação pautada nos valores morais burgueses da família e do bem supremo, desembocando em violência, maldade e malogro da felicidade. A obra, que foi classifica por Thomas Mann (1976) como uma das melhores de Kleist, ao lado do conto Michael Kohlhaas, narra a história de Piachi, um comerciante de terrenos que, em uma de suas viagens de negócios, vai a uma cidade que sofre pela peste acompanhado de seu filho de 11 anos, Paolo. Quando toma ciência do que ali se passava, o comerciante, temeroso pela vida de seu filho, resolve voltar para casa; porém, 
SILVA, C. Z. - A desconstrução da educação iluminista

no caminho, seu carro é interrompido por um jovem doente que lhe suplica ajuda. Delineando o caráter virtuoso de Piachi, o narrador nos diz que o velho resolve ajudar o jovem, comovido por sua situação. A ajuda, contudo, será a causa de um mal maior: Piachi, Paolo e Nicolo (o jovem) tem a viagem novamente interrompida, mas agora pela polícia que, apesar das exortações do velho comerciante, os envia ao hospital onde já haviam morrido os pais de Nicolo. Nesta armadilha inexorável do acaso (zufällig), Nicolo se cura e o filho de Piachi, contagiado pelo jovem, morre após três dias.

Este será o pano de fundo para a criação de uma história terrível, com um fim permeado por uma violência exacerbada e marcadamente caracterizada por um narrador intruso que intenta demonstrar imparcialidade, mas que, ao mesmo tempo, conduz o leitor a classificar os personagens entre o bem e o mal, de acordo com o seu ponto de vista. Piachi, logo de início, é caracterizado pelo narrador como o "guten Alten" 21 , que, destroçado pela morte de seu filho, convida o causador da desgraça para ocupar o lugar deste. Já Nicolo, apesar de ser mencionado como "Gottes Sohn"22, é, em uma observação mais atenta do jovem feita por Piachi, descrito como possuidor de uma beleza peculiar, que dá ao personagem uma feição bastante rígida e fria:

Er war von einer besonderen, etwas starren Schönheit, seine schwarzen Haare hingen ihm, in schlichten Spitzen, von der Stirn herab, ein Gesicht beschattend, das, ernst und klug, seine Mienen niemals veränderte. Der Alte tat mehrere Fragen an ihn, worauf jener aber nur kurz antwortete: ungesprächig und in sich gekehrt saß er, die Hände in die Hosen gesteckt, im Winkel da, und sah sich, mit gedankenvoll scheuen Blicken, die Gegenstände an, die an dem Wagen vorüberflogen. Von Zeit zu Zeit holte er sich, mit stillen und geräuschlosen Bewegungen, eine Handvoll Nüsse aus der Tasche, die er bei sich trug, und während Piachi sich die Tränen vom Auge wischte, nahm er sie zwischen die Zähne und knackte sie auf. (KLEIST 1982: 200-201) ${ }^{23}$

Ao virtuosismo e à bondade de Piachi são contrapostas as ações alheias (fremde) e rígidas (steif) de Nicolo, caracteristicamente ressaltadas por sua impassividade ao manipular as nozes frente à dor do velho, que acabara de demonstrar a máxima compaixão por ele. A psicologia dos personagens construída pelo narrador nos leva logo de início a desconfiar deste jovem de apenas 11 anos, que será, no final do conto, comparado a

\footnotetext{
21 "Velho bom."

22 "Filho de Deus."

23 "Ele era de uma beleza peculiar e um tanto rígida, o cabelo preto pendurado em sua testa em porções singelas, sombreando um rosto que, sério e sábio, nunca mudou sua expressão. O ancião lhe fez várias perguntas, às quais ele respondeu apenas brevemente: sentou-se calado e ensimesmado, com as mãos nos bolsos da calça, e observou com olhares tímidos e pensativos, os objetos pelos quais passava o carro. De vez em quando, com movimentos calmos e silenciosos, pegava um punhado de nozes do bolso e, enquanto Piachi limpava as lágrimas dos olhos, ele as colocava entre os dentes e as abria."
} 
SILVA, C. Z. - A desconstrução da educação iluminista

Tartufo, personagem de Molière, que designava o falso religioso, o hipócrita, e desnudará sua máscara de "höllischen Bösewichts"24.

Em poucas semanas, Piachi e sua segunda esposa Elvire já consideravam Nicolo como filho, enviando-o rapidamente à escola para que pudesse aprender a ler e escrever, e educando-o a partir do virtuosismo que definia o caráter moral desta família. Assim, com o passar do tempo, o jovem assumiu integralmente a vida do filho de Piachi e se tornou membro dessa família reconstruída, que já havia perdido a figura da mãe prontamente substituída por Elvire -, e que, agora, encontrava a sua alegria no menino. Contudo, à chegada da adolescência, o jovem mostrou uma disposição muito prematura para o sexo feminino, usando de suas visitas aos monges carmelitas - pelos quais Piachi não tinha nenhuma simpatia - para se encontrar com Xaviera Tartini, a concubina do bispo de quem Nicolo havia se enamorado.

Com uma linguagem concisa e enfática, o narrador expõe Nicolo como um homem aberto aos vícios que a adolescência lhe propiciava: a luxúria, apesar dos bons exemplos apresentados por seu padrasto e sua madrasta, ganhava força como móbile de sua vontade. Ainda assim, com vinte anos o jovem se casa com Constanza Parquet, sobrinha de Elvire, que havia sido por ela educada em Roma, apaziguando, pelo menos aparentemente, as preocupações de seus pais quanto ao seu desvio de conduta. Como forma de agraciá-lo pela atitude, Piachi e Elvire concederam-lhe uma parte considerável da espaçosa e bonita casa em que viviam, e o velho, ao completar sessenta anos, legou a ele toda a sua fortuna, ficando apenas com uma pequena parte para garantir o seu sustento e o de sua esposa. Depois de um ano de casados, Constanza deu à luz a um filho de Nicolo, porém, morreu juntamente com ele, o que fez com que as portas para as paixões do jovem fossem novamente abertas. Sem limites para o seu vício, Nicolo, no dia do funeral de sua esposa, é encontrado por Elvire no quarto do casal com Xaviera Tartini. Mais uma vez o acaso (“zufällig”) se mostra presente. Piachi, retornando de viagem, encontra Xaviera em sua casa e, energicamente, retira de sua mão uma carta que esta levava. Na carta, Nicolo lhe suplicava que marcasse um dia e um horário para encontrá-la. Piachi, enfurecido, respondeu à carta como se fosse Xaviera, pedindo que ele a encontrasse naquele dia mesmo, antes do anoitecer, na igreja Madalena. O jovem, sem pensar no corpo da esposa que estava na capela, foi ao encontro de Xaviera; porém, ludibriado por Piachi, deparou-

24 "Vilão infernal." 
SILVA, C. Z. - A desconstrução da educação iluminista

se na igreja o cortejo de Constanza e, extremamente envergonhado, passou a ter um profundo ódio por Elvire, acreditando que ela o havia denunciado a seu pai.

Como há uma linha tênue entre ódio e paixão (no caso do jovem, luxúria), Nicolo começa a se interessar sexualmente por Elvire, já que não acreditava que, com tantas tentações quantas existem, Elvire nunca tinha se aventurado. Um dia, passando em frente ao quarto dela, a ouviu conversar com alguém; porém, Piachi não estava na cidade, o que lhe deu esperanças de ter encontrado a ocasião perfeita. Olhou pela fechadura da porta e a viu aos pés de alguém, falando com todo amor e desejo: “Colino!”. Entusiasmado com a possibilidade de desfazer a áurea virtuosa de Elvire, Nicolo ficou à espreita, esperando que alguém saísse do quarto, mas sem sucesso. Ele, indignado com sua ousadia e hipocrisia, entrou no quarto em busca da pessoa que estava com ela. Contudo, para sua surpresa, não encontrou nada, apenas o retrato de um jovem cavaleiro em tamanho natural, colocado em um nicho na parede, atrás de uma cortina de seda vermelha, iluminado por uma luz especial. Com esta ideia fixa na cabeça, Nicolo levou Xaviera e a filha desta para ver o retrato. A menina, ao olhar para o quadro, notou imediatamente a semelhança entre Nicolo e Colino, colocando-o extremamente eufórico pela possibilidade de ter despertado a paixão em Elvire, uma mulher tão virtuosa:

Der Gedanke, die Leidenschaft dieser, als ein Muster der Tugend umwandelnden Frau erweckt zu haben, schmeichelte ihn fast eben so sehr, als die Begierde, sich an ihr zu rächen; und da sich ihm die Aussicht eröffnete, mit einem und demselben Schlage beide, das eine Gelüst, wie das andere, zu befriedigen, so erwartete er mit vieler Ungeduld Elvirens Wiederkunft, und die Stunde, da ein Blick in ihr Auge seine schwankende Überzeugung krönen würde. (KLEIST 1982: 209) ${ }^{25}$

A juventude de Elvire é, para Nicolo, incompatível com a virtude por ela expressa. Portanto, encontrar um defeito na jovem significaria para o personagem uma aproximação entre o caráter dos dois, quebrando, assim, essa áurea de ser superior carregada tanto por Elvire quanto por Piachi. Retomando o texto Allerneuester Erziehungsplan, podemos confrontar a relação dos pais adotivos com o adotado: diante destes exemplos magnânimos de boa vontade, Nicolo tende a ver e a buscar, seguindo a lei da contradição, apenas as possíveis falhas do virtuoso casal. Além disso, esse virtuosismo extremado clarifica sua incapacidade de acompanhar estes bons exemplos, o que o faz desistir do

\footnotetext{
25 "O pensamento de ter despertado a paixão desta mulher, que era um modelo de virtude, quase o lisonjeava tanto quanto o desejo de vingá-la; e, posto que se abriu para ele a perspectiva de satisfazer os dois desejos com um mesmo golpe, tanto um como o outro, ele esperava com grande impaciência o retorno de Elvire, e a hora em que um olhar em seus olhos coroaria sua vacilante convicção.”
} 
SILVA, C. Z. - A desconstrução da educação iluminista

pressuposto da moralidade pura. O pai e a mãe de virtude exemplar acabam por outorgar, pela negligência, um filho de vício exemplar.

Segundo Séan Allan,

His [Piachi's] treatment of the boy increases his pre-existing sense of his own worthlessness and renders him incapable of loving himself (and others). And having been denied the capacity to love by Piachi's (oppressive) benevolence, Nicolo seeks to assert his freedom through the only other channel at his disposal: hate. (ALLAN 2001: 159) ${ }^{26}$

Para o autor (Allan 2001), os presentes que Piachi dá para Nicolo garantem um efeito contrário ao pretendido, pois, por um lado, evidenciam a benevolência e o poder do pai adotivo e, por outro, clarificam essa nulidade do menino órfão. Assim, Allan (2001: 159) nos diz que não podemos ver o mal que se instala na vida de Piachi e Elvire como algo aleatório, fruto do destino, mas sim como produto das próprias ações de Piachi. No entanto, acreditamos que esta interpretação desconsidera a inicial caracterização do personagem. Ao atribuir a culpa de todo mal a Piachi, ignoramos que Nicolo, desde o início, com a doença, foi aquele que trouxe o mal para a vida de Piachi. Considerando o fator educação como uma parcela das milhares de outras situações que interferem na formação do ser humano, não podemos atribuir apenas a essa formação dada por Piachi e Elvire, feita após 11 anos de vida do jovem, toda a má conduta de Nicolo. Se pensarmos na cena inicial, em que o jovem quebra os amendoins nos dentes enquanto Piachi sofre a perda de seu filho, podemos perceber que a dinâmica na qual Nicolo viveu até aquele momento foi a de presenciar a dor de milhares de pessoas que perderam seus parentes pela peste, o que o tornou imune ao sentimento de compaixão. Ele mesmo já havia passado por semelhante dor na perda de seus pais. A formação de Nicolo até aquele momento era a de lutar por sua própria sobrevivência; ao conseguir alcançá-la, não faz sentido se importar com o sofrimento alheio. Assim, quando o horror e a dor se tornam habituais, eles impossibilitam que o ser sinta compaixão pelo próximo.

Outro fator relevante se refere à proximidade que podemos perceber entre os personagens Elvire e Nicolo. A esposa de Piachi, em sua infância, passou por um grave acidente: sua casa pegou fogo e ela, prestes a morrer, foi salva por um jovem cavaleiro genovês, que entrou na casa em chamas e a salvou com bravura. Porém, o jovem, de nome Colino, ficou gravemente ferido e, depois de três anos sofrendo e sendo cuidado pela

\footnotetext{
26 "Seu tratamento com o menino aumenta seu senso pré-existente de sua própria inutilidade e o torna incapaz de amar a si mesmo e aos outros. E, tendo sido negada a capacidade de amar pela benevolência de Piachi (opressiva), Nicolo procura afirmar sua liberdade através dos únicos outros canais à sua disposição: o ódio."
} 
SILVA, C. Z. - A desconstrução da educação iluminista

moça, morreu. Piachi, que costumava fazer negócios com ele, conheceu Elvire em sua casa, casando-se com ela dois anos depois da morte de Colino. O velho Piachi foi, dessa forma, aquele que deu a segurança de seu nome a Elvire e a Nicolo, importante fator social, acolhendo-os muito jovens e provendo-os não só financeiramente como também em termos de educação moral a partir de seu bom exemplo. Neste processo pedagógico, temos um caso de sucesso e um de fracasso: Elvire é extremamente grata pela ajuda de Piachi, e Nicolo não. Entretanto, a fraqueza de Elvire e a sua constante debilidade mostram que o seu virtuosismo é mais proveniente dessa fraqueza diante do mundo do que fruto do seu livre-arbítrio. Já Nicolo tem uma vontade forte, decisória e agente que o torna alguém que poderia encaminhar o arbítrio para o virtuosismo, mas decidiu por si mesmo conduzi-lo ao vício, evidenciando aquele poder criador do mal que Kleist destaca em seu Allerneuester, em detrimento da simples imitação de virtudes.

Para Allan (2001), esta diferença entre os dois pode ser explicada pelo papel exercido por Piachi na formação dos dois jovens. Ele não é nem o pai nem o amor natural de Elvire, pois esta teve uma educação afetiva dada pelos pais e vivenciou o verdadeiro amor com Colino, que se propôs a arriscar sua vida por ela. Isso a tornou capaz de saber retribuir qualquer forma de carinho que lhe fosse dirigida. Já Nicolo não teve a experiência de ter a educação completa dada por seus pais, pois os perdeu muito precocemente. Além disso, ele encontrou a paixão (e não o amor) no auge de sua adolescência na figura da amante do bispo, o que faz com que o seu primeiro contato com o sexo feminino se dê não por via do sentimento amoroso, mas sim em meio à transgressão e ao vício. Assim, a valoração dada pelos personagens a Piachi divergem justamente pela raiz de sua formação e pelo meio social, cultural e econômico em que estavam inseridos: Elvire teve como base de sua formação o sentimento natural, enquanto Nicolo já havia passado por desgraças múltiplas que o impediam de entender essa moralidade incompleta que lhe tentavam impor.

Esse sentimento antinatural presente na vida de Nicolo pode ser compreendido dentro da estrutura familiar que Piachi lhe apresenta. Se pensarmos na importância da constituição familiar para a época, percebemos que Nicolo e Elvire tornam-se peças de substituição na vida de Piachi, pois ocupam o lugar da esposa e do filho mortos, formando uma família não natural, construída pela oportunidade e não pelo sentimento. Segundo Mehigan (2011), as tentativas de Piachi de simular uma família artificial não aparecem no texto de Kleist como uma crítica a este tipo de constituição familiar, exaltando a 
SILVA, C. Z. - A desconstrução da educação iluminista

família "natural", mas sim como uma crítica a esse artificialismo de sentimento fundamentado em uma educação racional e social que descarta o princípio comum de união (natural, portanto) e estabelece valores forçados por essa dinâmica familiar artificial. Para Peter-André Alt,

Der Findling erzählt eine Geschichte vom Ende der Aufklärung, über das Scheitern einer rational begründbaren praktischen Ethik, die der späte Foucault als das entscheidende Kennzeichen der Epoche des Lichts und ihrer moralischen Programmatik aufgefaßt hat. (ALT 2011: 214) $)^{27}$

Dessa forma, a educação racional iluminista não garante o fim pretendido. Há uma lacuna entre a intenção que se tem ao ensinar e o seu resultado efetivo. Os ideais racionais de Piachi esbarram, assim, em um menino que não pertence a estes ideais. Ao tentar colocar Nicolo no lugar de seu filho e educá-lo a partir do rigorismo da educação moral iluminista, Piachi desconsidera a bagagem emocional e formativa que Nicolo já trazia consigo. Assim, o questionamento latente na narrativa pode ser o seguinte: a educação iluminista conseguiria alcançar sucesso em detrimento da ordem natural das coisas? Para Rousseau,

$\mathrm{Na}$ ordem social, em que todos os lugares estão marcados, cada um deve ser educado para o seu. [...] A educação só é útil na medida em que sua carreira acorde com a vocação dos pais [...]. Mas, entre nós, quando somente as situações existem e os homens mudam sem cessar de estado, ninguém sabe se, educando o filho para o seu, não trabalha contra ele. (ROUSSEAU 1995: 15)

Em outra passagem:

É o momento de corrigir as más inclinações do homem; é na infância, quando as penas são menos sensíveis, que é preciso multiplicá-las, a fim de poupá-las na idade da razão. Mas quem vos diz que todo esse arranjo está à vossa disposição e que todas essas belas instruções com que encheis o fraco espírito de uma criança, não lhe serão um dia mais perniciosas do que úteis? (RoUSSEAU 1995: 61)

No caso de Piachi, esta educação lhe foi mais perniciosa do que útil, pois Nicolo usou materialmente dos objetos empregados nesta educação para objetivar o seu projeto de vingança contra Elvire. O narrador nos conta que, certo dia, Piachi lembrou de uma caixa com "pequenas letras de marfim" ("kleinen, elfenbeinernen Buchstaben") que haviam sido usadas na educação de Nicolo em sua infância, e pediu para que sua empregada as encontrasse, pois as daria de presente a uma criança da vizinhança. Ela, coincidentemente, localizou apenas as letras que formavam o nome Nicolo. Um dia, o jovem, sentado à mesa, começou a brincar com estas letras e assombrosamente descobriu

27 "Der Findling conta uma história do fim da Aufklärung, sobre o fracasso de uma ética racional substancialmente prática, que o tardio Foucault percebeu como indicador do final da era das luzes e sua programática moral." 
SILVA, C. Z. - A desconstrução da educação iluminista

que elas, reorganizadas, formavam o nome Colino. Isso foi para ele a confirmação de seus delírios:

Die Übereinstimmung, die sich zwischen beiden Wörtern angeordnet fand, schien ihm mehr als ein bloßer Zufall, er erwog, in unterdrückter Freude, den Umfang dieser sonderbaren Entdeckung, und harrte, die Hände vom Tisch genommen, mit klopfendem Herzen des Augenblicks, da Elvire aufsehen und den Namen, der offen da lag, erblicken würde. Die Erwartung, in der er stand, täuschte ihn auch keineswegs; denn kaum hatte Elvire, in einem müßigen Moment, die Aufstellung der Buchstaben bemerkt, und harmlos und gedankenlos, weil sie ein wenig kurzsichtig war, sich näher darüber hingebeugt, um sie zu lesen: als sie schon Nicolos Antlitz, der in scheinbarer Gleichgültigkeit darauf niedersah, mit einem sonderbar beklommenen Blick überflog, ihre Arbeit, mit einer Wehmut, die man nicht beschreiben kann, wieder aufnahm, und, unbemerkt wie sie sich glaubte, eine Träne nach der anderen, unter sanftem Erröten, auf ihren Schoß fallen ließ. (KLEIST 1982: 210) ${ }^{28}$

As letras que foram utilizadas para o seu ensinamento metaforizam, dessa forma, o encaminhamento dado por Nicolo a esta educação. De maneira engenhosa, Kleist critica os processos pedagógicos que veem, em sua estrutura formal, a garantia de sucesso do caráter moral do ser humano, demonstrando que esta formação pode ser empregada tanto para o bem quanto para o mal, pois está interligada aos vários fios aos quais o ser humano está preso. O jogo de substituições empreendido por Piachi, esta estrutura antinatural, é assimilada por Nicolo como uma proposta de substituição nas intenções de Elvire, formando, assim, o simulacro de uma paixão desta por ele. Para Umberto Eco (2010: 269), se pensarmos a razão humana, conforme postulado por Kant, como uma força que, para tornar-se independente, necessita reduzir todos os objetos da natureza a conceitos, os quais, por sua vez, tornam-se seu domínio, dos quais se pode fazer qualquer uso, como podemos impedi-la de reduzir não só os objetos, mas também as pessoas a esta categoria, tornando-as objetos de manipulação? A formação pedagógica moral tem por intuito levar o educando a abdicar deste uso irrestrito da razão; porém, como questiona Eco (2010: 269), "quem pode impedir o planejamento racional do mal e a destruição dos corações alheios?”. A lógica de Rousseau (1995: 108) no ensino das crianças com as fábulas se encaixa nesta disposição moral de Nicolo:

Observai as crianças aprendendo suas fábulas e vereis que, quando em condições de aplicá-las, elas o fazem quase sempre ao contrário da intenção do autor que, ao invés de

\footnotetext{
28 "A correspondência entre as duas palavras the pareceu mais do que mera coincidência: ele considerou, em alegria reprimida, a extensão dessa descoberta curiosa e, com as mãos tiradas da mesa, seu coração batendo forte, esperou que Elvire olhasse para cima e visse o nome que lá estava exposto. A expectativa em que ele permaneceu não o enganou; assim que Elvire notou, em um momento ocioso, a formação das letras, inocente e irrefletida, porque ela era um pouco míope, curvou-se para lê-la: quando ela já havia sobrelevado um olhar estranhamente ansioso para o rosto de Nicolo, que, aparentemente, olhava para baixo com indiferença, retomou seu trabalho com uma melancolia que não pode ser descrita e, crendo-se despercebida, soltou uma lágrima após a outra, corando suavemente sobre o colo."
} 
SILVA, C. Z. - A desconstrução da educação iluminista

atentarem para o defeito de que lhes querem curar ou prevenir, elas se inclinam para o vício mediante o qual se tira proveito dos defeitos dos outros. [...] Ninguém gosta de se humilhar; escolherão sempre o melhor papel. (ROUSSEAU 1995: 108)

Nicolo já havia sido humilhado por Piachi e Elvire, portanto a sua vingança é alcançar uma posição superior à dos dois. As letras mostram para ele que o caminho para a humilhação de Elvire passa pela relação entre ele e o quadro. Porém, ele ainda não se deu conta de que o verdadeiro fundamento da dor de Elvire é, na verdade, Colino. O jogo entre aparência e essência, tão presente na literatura de Kleist, mostra-se aqui como o engano no qual cai Nicolo ao acreditar que Colino era na verdade um codinome criado por Elvire para esconder sua paixão por ele. A relação aparente mãe-filho está, dessa forma, completamente desfeita, pois, como destaca o narrador, Nicolo está imbuído de "unnatürlichen Hoffnungen" 29 , que serão quebradas quando ele descobre a real história de Elvire. O virtuosismo da madrasta é reconstituído, o que desencadeia em Nicolo um desejo ainda maior de romper com essa superioridade moral:

Beschämung, Wollust und Rache vereinigten sich jetzt, um die abscheulichste Tat, die je verübt worden ist, auszubrüten. Er fühlte wohl, daß Elvirens reiner Seele nur durch einen Betrug beizukommen sei; und kaum hatte ihm Piachi, der auf einige Tage aufs Land ging, das Feld geräumt, als er auch schon Anstalten traf, den satanischen Plan, den er sich ausgedacht hatte, ins Werk zu richten. (KLEIST 1982: 212) ${ }^{30}$

Os móbiles que impulsionam a sua ação serão "vergonha, luxúria e vingança", totalmente contrários ao bem supremo que deveria ser a base fundamental da sua vontade. Se o engano (Betrug) havia levado o personagem a esse exacerbamento de emoções, seria ele também que possibilitaria o desvirtuamento da casta mãe. Segundo Eco,

A crueldade coincide, portanto, com a natureza humana, o sofrimento é o meio para alcançar o prazer, único fim em um mundo iluminado pela luz violenta de uma razão sem limites que povoa o mundo com seus pesadelos. A Beleza dos corpos não tem mais nenhuma conotação espiritual, exprime apenas o prazer cruel do carnífice ou o suplício da vítima, sem nenhum adorno moral: é o triunfo do reino do mal no mundo. (ECO 2010: 269)

A escolha desse uso sem limites da razão faz com que Nicolo encontre na crueldade e no sofrimento de Elvire o prazer, que será concretizado através da posse de seu corpo. Em referência clara à ação de Zeus no ludíbrio de Alcmena, na peça Amphitryon, cuja versão de Kleist é de 1803, Nicolo, aproveitando-se de sua semelhança com Colino, veste-se de cavaleiro genovês, entra no quarto de Elvire pouco antes da hora

\footnotetext{
29 "Esperanças antinaturais."

30 "Vergonha, luxúria e vingança foram unidas agora para criar a mais hedionda ação já cometida. Ele estava certo de que a alma pura de Elvire só poderia ser superada por um engano [Betrug]; e logo que Piachi partiu para o campo por uns dias, o terreno estava limpo para que ele pudesse colocar em ação o plano satânico que ele havia planejado."
} 
SILVA, C. Z. - A desconstrução da educação iluminista

desta dormir e toma o lugar do quadro do jovem. Elvire, ao notar Colino/Nicolo vivo, desmaia. O jovem a leva para a cama e tenta estuprá-la, "aber die Nemesis, die dem Frevel auf dem Fuß folgt, wollte, daß Piachi, den der Elende noch auf mehrere Tage entfernt glaubte, unvermutet, in eben dieser Stunde, in seine Wohnung zurückkehren mußte"31 (KLEIST 1982: 213). Os elementos paradoxais da condição humana, o bem e o mal, dividem-se na narrativa de Kleist em dois personagens: Nicolo e seu duplo Colino apresentam uma identidade aparente no mundo físico que se desfaz completamente no mundo moral. Essência e aparência revelam-se neste jogo de substituições empreendido pelos personagens, que atinge o seu ápice na substituição do quadro de Colino pelo homem Nicolo para a prática do ato perverso. Segundo Peter-André Alt (2011) a cena da tentativa de estupro de Elvire por Nicolo é estruturada a partir das características do romance gótico e mantém uma proximidade muito grande com uma cena do livro The monk (1797), de Matthew G. Lewis, em que o monge Ambrosio é convencido pelo diabo a estuprar Antonia, porém é interrompido no ato pela mãe da jovem, Elvira. Coincidência ou não entre os nomes das personagens, Alt evidencia a relação intertextual estabelecida entre as duas obras a partir do próprio vocabulário utilizado pelos autores: desejo, ofensa e vergonha atendem como móbiles da ação de violação do corpo da figura feminina pelos personagens Nicolo e Ambrosio. A caracterização gótica do conto de Kleist se dá, assim, pela criação de uma ambientação soturna e fantasmagórica que irá ressuscitar o morto Colino para a prática de um ato horrendo através de seu duplo Nicolo.

A sequência da narrativa expõe que, após o seu ápice, a perversidade de Nicolo, sem mais retorno, provocará também a derrocada de Piachi. Consciente de que seu ato acarretaria sérias consequências, o jovem rogou clemência aos pés do ancião, que "in der Tat, war der Alte auch geneigt, die Sache still abzumachen"32 (KLEIST 1982: 213). Porém, não obtendo resultado, Nicolo expulsa Piachi de sua própria casa, afirmando que tinha documentos que provavam que a casa e a fortuna do velho lhe pertenciam. Elvira falece como consequência do ato de Nicolo e, desamparado, Piachi procura um amigo jurista, que encaminhou várias diligências em favor de sua causa; porém, Nicolo, vinculado aos monges carmelitas, encontrou nestes a ajuda necessária: o jovem consentiu em se casar com Xaviera, da qual o bispo queria se ver livre, e "siegte die Bosheit"33 (KLEIST 1982:

\footnotetext{
31 "Porém Nêmeses, que segue no pé do crime, quis que Piachi, o qual o desgraçado acreditava que ainda estaria ausente por vários dias, retornasse inesperadamente, naquela hora, à casa dele."

32 "De fato, o velho estava inclinado a silenciar o assunto".

33 "A maldade venceu."
} 
SILVA, C. Z. - A desconstrução da educação iluminista

214), pois o governo promulgou, a pedido do bispo, a posse de Nicolo sobre os bens de Piachi. Desnudadas todas as aparências da feliz família burguesa e da corrupção a que a instituição religiosa está sujeita, Piachi,

Durch diesen doppelten Schmerz gereizt, ging er, das Dekret in der Tasche, in das Haus, und stark, wie die Wut ihn machte, warf er den von Natur schwächeren Nicolo nieder und drückte ihm das Gehirn an der Wand ein. Die Leute die im Hause waren, bemerkten ihn nicht eher, als bis die Tat geschehen war; sie fanden ihn noch, da er den Nicolo zwischen den Knien hielt, und ihm das Dekret in den Mund stopfte. Dies abgemacht, stand er, indem er alle seine Waffen abgab, auf; ward ins Gefängnis gesetzt, verhört und verurteilt, mit dem Strange vom Leben zum Tode gebracht zu werden. (KLEIST 1982: 214) ${ }^{34}$

A violência empregada por Piachi revela que o desmantelamento das aparências foi fundamental para a mudança de sua atitude passiva diante das ações do jovem. Se, socialmente, as falhas de Nicolo até então estavam veladas, mantendo a aparência de felicidade da família formada - assim como o culto de Elvire pelo quadro dentro de seu quarto não o afetava socialmente -, a revelação deste problema fora das paredes da casa expunha a hipócrita ligação platônica entre pai, mãe e filho que imperava nesta família. Nicolo destrói, mais uma vez, o projeto de felicidade do bom burguês Piachi, que necessitava desta estrutura familiar, mesmo que nela não circulasse de nenhuma forma $o$ amor e a bondade de fato, para manter a aparência de felicidade que o sustentava. Não é de se estranhar que Piachi abdique de tudo o que possui para que Nicolo mantenha-se no caminho da retidão ou mesmo cogite esquecer a tentativa de estupro de Elvire pelo jovem. O que importa nesta realidade artificial é a aparência de felicidade e de bondade, pois a felicidade, a bondade e o amor morreram junto com o amor natural existente na primeira constituição dessa família. Kleist demonstra, neste conto, o artificialismo que tenta barrar a solidão do ser humano no mundo; mesmo sem laços afetivos, há que estar junto de outrem para que a solidão não se afirme. A família artificial é, dessa forma, a maneira aceita socialmente de aplacar a solidão e manter o status e os valores do ser virtuoso.

Considerando Piachi por este aspecto, podemos perceber que a figura exemplar por ele representada também sobreleva à bondade pura um interesse. Os seus atos de compaixão com o próximo, no caso Elvire e Nicolo, são também uma forma de atender a uma necessidade própria, que não é em nenhum momento questionada pelo narrador nada imparcial do conto, assim como a bizarrice do culto de Elvire também não é por ele

\footnotetext{
34 "Irritado por essa dor dupla, ele foi, com o decreto no bolso, para a casa, e forte, como a ira o fez, jogou Nicolo, naturalmente mais fraco, e pressionou seu cérebro contra a parede. As pessoas que estavam na casa não o notaram até o ato ter acontecido; eles o encontraram ainda segurando Nicolo entre os joelhos e enchendo sua boca com o decreto. Feito isso, levantou-se, desistindo de todas as suas armas; foi colocado na prisão, interrogado e condenado a ser morto na forca."
} 
SILVA, C. Z. - A desconstrução da educação iluminista

condenada. Este narrador é, de certa forma, do mesmo veio do editor que comenta a carta de Levanus: tudo que atenda, mesmo que aparentemente, à moral e aos bons costumes não deve ser objetado. Assim, a parcialidade do narrador se mostra ainda maior quando, condenado à morte, Piachi nega a absolvição que o Estado eclesiástico é obrigado a lhe conceder e, assim como Kohlhaas, abdica do contrato social para empreender a sua vingança contra Nicolo, pois apenas a morte violenta deste não foi suficiente diante dos males causados na vida do bom velho:

Ich will nicht selig sein. Ich will in den untersten Grund der Hölle hinabfahren. Ich will den Nicolo, der nicht im Himmel sein wird, wiederfinden, und meine Rache, die ich hier nur unvollständig befriedigen konnte, wieder aufnehmen! (KLEIST 1982: 214-215) ${ }^{35}$

Não há, ao contrário do que ocorre com Nicolo, nenhuma palavra de condenação do narrador, apenas a atribuição destas desgraças ao impiedoso destino, fazendo com que o leitor passe a desconfiar desta instância narrativa e reflita mais detidamente sobre os fatos ocorridos.

A leitura da maldade e da bondade neste conto deve, dessa forma, considerar duas vertentes: a primeira é revelada pela figura de Nicolo, que desde o primeiro momento se mostra propenso aos vícios, desenvolvendo-se a partir desta propensão. Já Piachi representa o moralismo kantiano às avessas: se o "acaso" até agora encaminhou Piachi à desgraça e ao mal, renunciar à sua virtude (ou imitação de uma boa conduta) é afirmar o seu arbítrio; por mais retidão que intente empregar no mundo, mesmo que esta seja fruto do auto interesse, nada lhe garante que o seu projeto de felicidade terá eficácia. Há um fatalismo nesta proposição que evidencia um homem que lutou sempre para o bem, mas que, ao fim, vê o mal triunfar. Ao descobrir sua autonomia na escolha do bem e do mal, Piachi optará por aquilo que satisfaça o seu desejo de vingança; se até aquele momento exercer o virtuosismo trouxe para sua vida uma rede de desgraças das quais ele, pela boa vontade tão aclamada por Kant, não conseguiu se desvencilhar, ser mau possibilitaria ao bom velho a sensação de justiça que as leis humanas (nestas, incluídas as leis divinas através da instituição religiosa representada pelos monges carmelitas) não foram capazes de lhe proporcionar. A motivação da transformação de Piachi se encontra, dessa forma, em uma lógica iluminista idealizada que fracassa na realidade empírica. A "livre-escolha" nos parece, dessa forma, ser determinada por este zufällig que permeia todos os acontecimentos do conto, até desembocar no mal (Böse) completo. Se o mal de Nicolo

\footnotetext{
35 "Eu não quero ser salvo. Eu quero descer até o abismo mais profundo do inferno. Quero reencontrar Nicolo, que não estará no céu, e retomar minha vingança, que só pude satisfazer parcialmente aqui!"
} 
SILVA, C. Z. - A desconstrução da educação iluminista

pode ser considerado quase como uma característica intrínseca à sua personalidade, vemo-lo desenvolver-se em Piachi por meio dos paradoxos encontrados por ele durante a sua vida. Com Nicolo, Kleist não nega o ser humano mau em essência, mas determina certas atitudes que desembocam em uma reafirmação desta maldade, que propiciam o desenvolvimento da maldade em um grau superior. Não há explicações possíveis para esse mal que é incomensurável, há apenas indícios de que algo nessa educação não funcionou.

Diante deste cenário, podemos dizer que a modernidade de Kleist neste conto consiste, justamente, no modo como ele trata estas ações paradoxais, que são entrecortadas tanto pelo bem quanto pelo mal. A reflexão vai além da dicotomia bem e mal e atinge a perplexidade do leitor diante das circunstâncias que levaram este homem com certa solidez moral a agir com tamanha violência. A palavra, na materialidade do texto de Kleist, ganha uma dimensão dúbia, que se traduz na reflexão empreendida pelo leitor para a compreensão da obra. As diversas leituras daí provenientes provam que o simulacro criado por Kleist tem por intenção levar o leitor a dimensionar a moralidade e a educação proposta pelos filósofos iluministas em seus diversos pontos de contato com a realidade empírica, longe do ideal transcendente.

\section{Referências Bibliográficas}

Allan, S. The stories of Heinrich von Kleist: fictions of security. New York: Camden House, 2001.

ALt, P. Ästhetik des Bösen. München: Verlag C. H. Beck, 2011.

ECO, U. História da beleza. Tradução: Eliana Aguiar. Rio de Janeiro: Editora Record, 2010.

FICHTE, J. G. Discurso à nação alemã. In: VICENTI, L. Educação e liberdade: Kant e Fichte. Tradução: Élcio Fernandes. São Paulo: Editora da Universidade Estadual Paulista, 1994, p. 101-116.

KANT, I. Sobre a pedagogia. Tradução: Francisco Cock Fontanella. 3. ed. Piracicaba: Editora UNIMEP, 2002.

KANT, I. Resposta à pergunta: “O que é o Iluminismo?”. LusoSofia, Covilhã, 2008. Disponível em: http://www.lusosofia.net/textos/kant_o_iluminismo_1784.pdf. Acesso em: 25 jul. 2016.

KLEIST, H. Sämtliche Werke und Briefe in vier Bänden. München: Carl Hanser Verlag, 1982.

LEIBNIZ, G. W. Novos ensaios sobre o entendimento humano. Tradução de Luiz João Baraúna. 2. ed. São Paulo: Abril Cultural, 1984.

MANN, T. Kleist and his stories (Preface). In: KLEIST, H. von. The Marquise of $O$ and others stories. Translated and with an Introduction by Martin Greenberg. New York: Frederick Ungar Publishing Co, 1976, p. 5-23.

MeHIGAN, T. Heinrich von Kleist: Writing after Kant (Studies in German Literature Linguistics and Culture). Suffolk: Boydell \& Brewer Group, 2011. 
SILVA, C. Z. - A desconstrução da educação iluminista

MoreaU, J. Platão e a educação. In: ChÂTEAU, J. Os grandes pedagogistas. Tradução: Luiz Damasco Penna, J. B. Damasco Penna. São Paulo: Companhia Editorial Nacional, 1978, p. 21-39.

NoBILE, N. The school of days: Heinrich von Kleist and the traumas of education. Detroit: Wayne State University Press, 1999.

RousseaU, J. Emílio: ou da educação. Tradução: Sérgio Milliet. 3. ed. Rio de Janeiro: Bertrand Brasil, 1995.

Vincenti, L. Educação e liberdade: Kant e Fichte. Tradução: Élcio Fernandes. São Paulo: Editora da Universidade Estadual Paulista, 1994.

Recebido em 26 de setembro de 2019 Aceito em 1 de outubro de 2019 